\title{
Mapping Course Sustainability by Embedding the SDGs Inventory into the University Curriculum: A Case Study from National University of Kaohsiung in Taiwan
}

\author{
Ya-Ching Chang ${ }^{1}$ and Hsing-Lung Lien ${ }^{2, *}$ \\ 1 Imagination for Future School, Center for Teaching and Learning Development, National University of \\ Kaohsiung, Kaohsiung 811, Taiwan; yaching2@go.nuk.edu.tw \\ 2 Imagination for Future School, Department of Civil and Environmental Engineering, National University of \\ Kaohsiung, Kaohsiung 811, Taiwan \\ * Correspondence: lien.sam@go.nuk.edu.tw
}

Received: 28 March 2020; Accepted: 20 May 2020; Published: 22 May 2020

check for updates

\begin{abstract}
A course inventory module, based on the Curriculum Framework for the Sustainable Development Goals (SDGs) published by the Commonwealth Secretariat, has been embedded into the online curriculum system at the National University of Kaohsiung (NUK) since 2018. The primary aim of this study is to explore the sustainability status of the course offerings and to understand the interdisciplinary capacity in pursuing the SDGs at NUK. At the university level, a total of $1200-1300$ courses (approximately $57 \%$ of courses) were reported to be related to SDGs, where the curriculum of NUK mainly emphasized SDGs 3, 4, 8, 9 and 16. However, our study indicates that many SDGs are still not focused in the curriculum of all colleges. Two patterns of the SDGs-related course framework were observed at the college level: One is the college course offerings linked to a wide variety of SDG content; while the second pattern is the college course offerings linked only to specific SDG content, mainly dependent on the subject areas of colleges. Our study suggests that the number of SDGs covered by a course reflects the diversity of the sustainability topics covered in the course. The metric gives an indication of the areas covered and, thus, also points to blind spots (i.e., insufficiencies). Moreover, it can also give an indication of the diversity within colleges, which could suggest future paths for transdisciplinary development. An understanding of the baseline status of sustainability in the university curriculum provides opportunities for universities to plan their strategies for sustainability and prioritize the allocation of resources accordingly.
\end{abstract}

Keywords: sustainable development goals; SDGs; higher education; curriculum; course inventory; institutional research; faculty engagement; sustainability

\section{Introduction}

In 2015, the United Nations approved the 17 sustainable development goals (SDGs) as the new working framework for sustainable development, which is based on five pillars: people, prosperity, peace, partnership and the planet, in order to end poverty, protect our environment, and ensure prosperity for all [1]. The 17 SDGs highlight a global vision for sustainability, in which higher education institutions (HEIs) should play an important role [2-7]. HEIs are uniquely placed to link the local and global societies, educating young and future leaders and having a strong influence on decision-makers in many societies. Many leaders in all sectors of society, from government to private sectors, have graduated from HEIs. For example, all elected Presidents of Taiwan, to date, have been graduates of National Taiwan University [8]. According to the latest statistics released by 
the Taiwanese Ministry of the Interior (2020), 46\% of Taiwan's population aged 15 and above hold a technical college or university degree [9]. Therefore, if university graduates value the importance of sustainable development and are aware of SDGs, the transformation of society towards sustainability is more likely to happen.

Transitions are to be understood as a complex and long-term ambition to shift from analyzing and understanding problems towards identifying pathways and solutions for desirable environmental and societal change [10]. Sustainability transitions are long-term, multi-dimensional and fundamental transformation processes, through which established socio-technical systems shift to more sustainable modes of production and consumption [11,12]. In the case of higher education, a paradigm shift in education should be undertaken, in order to educate students in all degree programs to be SDG Literate [13]. Leal Filho pointed out that some key areas, including sustainability in the curriculum, sustainability on campuses, sustainability literacy, sustainability research, sustainability governance and sustainability reporting and thematic integration need to be accelerated in a higher education context [13]. As an example of the function SDGs can play in HEIs, Deleye et al. analyzed the Flemish higher education system using a multi-level perspective (MLP) on sustainability transitions, indicating that there are 16 opportunities for the further integration of sustainability into higher education [14]. Among them, SDGs can be seen multitools for a communication instrument and implementing sustainability education through competences can be an effective way to structurally embed sustainability in curricula [14].

HEIs are central players in the achievement of SDGs. Indeed, education has been identified as a standalone goal in the SDGs (SDG 4: quality education). Based on the analysis of $40 \mathrm{UN}$ flagship reports published between 2006-2015, it has been demonstrated that SDG 4 links with all other SDGs, except for SDG 14 (life below water) [15]. However, the vision offered by HEIs is too narrow and unable to capture the essence and full meaning of sustainable human development [16]. Universities have their comfort zone, where academics and departments may tend to rely on silo approaches in teaching and research activities $[4,16]$. It has been demonstrated that the major obstacles to implementing SDGs in universities include a lack of support from administration and management operation, a lack of interest in or concern with sustainability issues and a lack of structural units such as committees [17]. Lozano also reported that there are barriers that prevent universities from incorporating sustainable development into their institutional systems [18]. The resistances to change include a lack of information, psychological and emotional reactions towards change, unwillingness to co-operate to make changes, procrastination and power struggle issues [18]. To help universities to engage with the SDGs, the UN Sustainable Development Solutions Network (SDSN) has recommended that universities can contribute to the SDGs through four aspects;, namely, education, research, governance and operations and external leadership [19]. Besides the traditional missions of HEIs, the third mission of HEIs-emphasizing knowledge and technology transfer, further education and social engagement-has attracted attention [20]. As the third mission of HEIs, the engagement of pursuing the SDGs for HEIs which link up with external stakeholders and society should be considered an opportunity [21]. It helps to transform the curriculum by combining the content of courses with SDGs, creates funding streams to support research programs, and facilitates collaboration with society $[13,18,19,21]$. As such, the integration of SDGs and the concepts and principles of sustainable development into the curriculum of higher education is certain to be one of the dimensions of sustainability at universities.

The course inventory consists of courses that have been approved by the university. For each course, the basic information should be provided, including the course title, course instructors, course credits and course description (e.g., the syllabus). A study conducted by Penn's Integrating Sustainability Across the Curriculum (ISAC) program demonstrated that course inventories increase both student and faculty awareness of sustainability course offerings [22]. As pointed out in their study, the promotion of a course inventory fosters dialogue among students and underscores the inherently interdisciplinary aspects of sustainability across Penn's diverse course offerings [22]. According to the 
Sustainability Tracking, Assessment, and Rating System (STARS) developed by the Association for the Advancement of Sustainability in Higher Education (AASHE), an inventory of academic offerings conducted by HEIs provides an important foundation for advancing a sustainability curriculum [23]. It provides a baseline for understanding the current offerings and can help institutes to identify both strengths and opportunities for growth [23]. STARS has categorized sustainability courses into two types: sustainability-focused and sustainability-inclusive courses.

On the other hand, numerous studies have applied SDGs as indicators to evaluate the degree of integration of sustainability in the curriculum, from university to department level (see, e.g., [24-26]). For instance, Lovren et al. analyzed the outcomes defined in the curricula of subjects within their three faculties using the UNESCO learning objectives related to selected SDGs as a criteria at the University of Belgrade [24]; while a university-wide study was conducted by Albareda-Tiana et al. at the International University of Catalonia to explore the curricular implementation of topics linked to the SDGs using the degree reports of the university [25]. Surveys of the curriculum for course mapping with SDGs were found to be able to help staff and students to understand the SDGs in the university [27]. Universities who provide the annual sustainability reports are often required to report their sustainability curriculum as a basic component [28]. NUK has already established an online course inventory system which teachers can access to upload an individual course syllabus to the public since 2006 [29]. On the basis of this foundation, we have further embedded an SDGs course inventory module into the current online curriculum system, in order to explore the relationship between the curriculum and SDGs since 2018. Similar approaches have been applied in different HEIs. For example, Nottingham Trent University (NTU) has developed a university-wide system to integrate the SDGs into their core curriculum since 2016 [30]. The system entitled, "Curriculum Refresh" has been used to assess the sustainability content of the more than 640 courses at NTU. All courses at NTU are encouraged to explore how their disciplines can achieve the SDGs and how they can collaborate for the SDGs [30]. Though the use of SDGs as global indicators has been criticized as being too broad and confusing [21,31], our strategy is to embed the curriculum framework of SDGs into our course inventory system to assess the sustainability content of the course offerings and, through the process, to promote awareness about SDGs around the university. As a result, we collected data from the SDGs course inventory embedded online curriculum system for three consecutive semesters (from the fall semester of 2018 to that of 2019).

\section{The Context: Transforming National University of Kaohsiung towards Sustainability}

The National University of Kaohsiung (NUK) is the newest comprehensive national university in Taiwan, established in 2000. With approximately 5500 students and 250 full-time faculty members, the university is comprised of five colleges, a general education center, 21 departments, 23 master programs and 3 Ph.D. programs [32]. The five colleges include law, humanities and social sciences, management, science and engineering; a detailed academic organization structure can be found in Table 1 . The academic year of NUK is a two-semester system. Approximately 1200-1400 courses are offered each semester. As the university was established in the current millennium, NUK strives to embrace sustainability as one of the university's core values. Therefore, NUK was the first Taiwanese university to sign the Talloires Declaration in 2004.

The first stage (2004-2015) of the sustainability transitions at NUK was focused on the "hardware" infrastructure [33]. NUK established a water recycling system which recovers up to $85 \%$ of wastewater for reuse inside the campus. The campus buildings accredited as green buildings were all constructed based on the green building labeling system regulations in Taiwan. In addition, a solar panel system was installed on the roof of the buildings in 2005 and a 1.2-MW total solar photovoltaic system was further completed in 2018. It can be seen that the efforts of NUK during this first stage are part of the "sustainability on campuses" idea.

In the second stage (2016-present), NUK realized that the SDGs can serve as a "common language" which bridges NUK to higher education communities around the world. Therefore, NUK started 
its transition to "software" infrastructure and proposed an SDGs-Inside policy as guidance for the university's long-term development plan in 2018 [33]. The SDGs-Inside policy of NUK, approved by the University Council (the highest authority of the university), is to commit the university to embed sustainability across all aspects and, therefore, support and promote the SDGs through our research, education and operations [33]. To strengthen the connection with its external partners, NUK became one of the founding members of The Alliance for sustainable development goals (A.SDGs) established by Taiwan Institute for Sustainable Energy (TAISE) in 2018. The Alliance, including 11 governmental agencies, 12 universities, 44 corporations, five think-tank research institutions and 11 non-governmental organizations, is the largest Taiwanese SDG platform serving to foster Taiwan's sustainable development [34]. As part of the university's social responsibility, NUK has published an annual sustainability report since 2018 and collaborated with TAISE through the Alliance to offer corporate social responsibility (CSR) lectures, training courses for SDGs in higher education and a cross-sectoral SDG forum. In regional collaborations, Sunway University of Malaysia, Srinakharinwirot University of Thailand, and NUK have established an annual Universities for SDG Forum to exchange scientific materials and joint research since 2019 [35].

NUK participated, for the first time ever, in university ranks that are based on the outcomes of implementation of SDGs conducted by the Times Higher Education (THE) [36]. The THE University Impact Rankings opens a new horizon: that the evaluation of a university's performance no longer relies on achievements in academia. The bigger trend is to look at their impact at a broader level, including society, environment and partnerships. The motivation of the authors to initiate this research on the SDGs course inventory - to understand the baseline status of the university curriculum as an aspect of sustainability of NUK - was conceived due to the processes inspired by the THE University Impact Rankings, capturing the impact of universities on society based on institutional successes in delivering the SDGs [36].

In this study, we investigate the curriculum framework associated with SDGs at NUK at the department, college and university levels. The objectives of the research are aimed at: (1) establishing a baseline status of sustainability in the overall curriculum of NUK through the distribution of SDGs-related courses at different levels, (2) understanding the interdisciplinary capacity of the faculty members in pursuing the SDGs and (3) offering evidence-based practice for departments to reform their curriculum by integrating SDGs. The SDGs course inventory provides opportunities to gain insights into the whole structure of the curriculum framework, such that a university may plan its strategy for sustainability accordingly.

\section{Methods}

This research was undertaken as a case study, where the research framework of the study indicating the following steps is shown in Figure 1.

1. Data collection-Using the NUK online syllabus system embedded with a SDGs course inventory module to collect sustainability data of courses;

2. Data analysis-Investigating the current curriculum framework associated with SDGs at NUK at the department, college and university level and virtualizing the results for in-depth interpretation;

3. Dimension analyzed-Based on the objectives, analyses were conducted in three dimensions: First, to understand the distribution of SDGs-related courses at different levels. Second, to determine the most relevant SDGs respect to different colleges. Third, the interdisciplinarity analysis measured by the diversity of SDGs. Finally, the potential outcomes that may apply to those wishing to take a similar approach are recommended. 


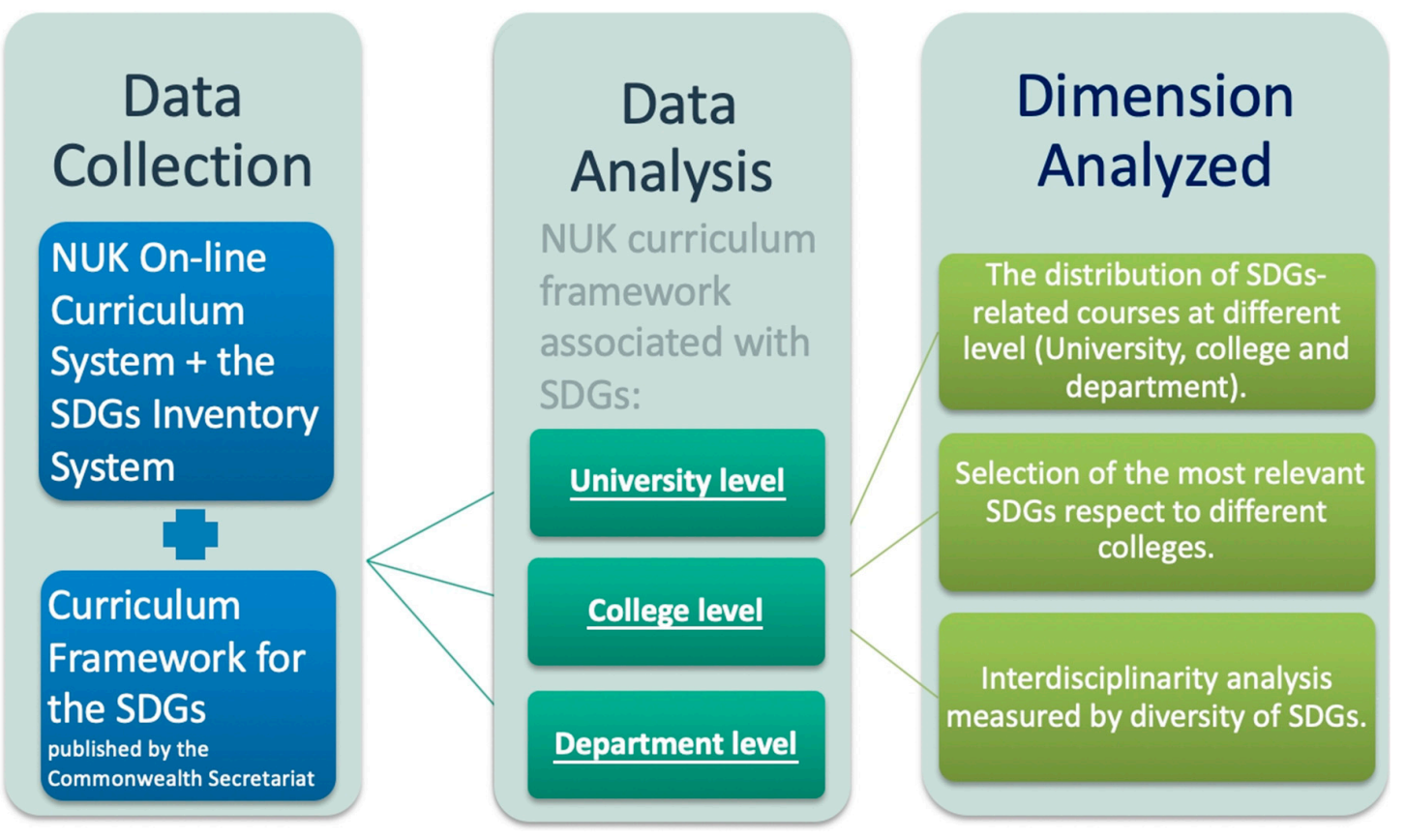

Figure 1. Research framework of the study.

\subsection{Data Collection}

Different methodologies for creating a sustainability course inventory have been developed in both qualitative and quantitative research, such as a survey of academic faculty and keyword search of course catalogue [23-26]. As mentioned above, AASHE recommends reporting sustainability courses (i.e., sustainability-focused and sustainability-inclusive courses), justified by the course title, course description and an indication of qualification [24]. We used our online syllabus system embedded with a SDGs inventory module to collect sustainability course data. The content of the SDGs inventory is based on the Curriculum Framework for the Sustainable Development Goals published by the Commonwealth Secretariat [37]. The competencies provided by Commonwealth Secretariat are specified in three categories, namely, knowledge, skills and values [37]. A systematic matrix model with indicative core competencies can be readily used for programing. Thus, the inventory system consists of two levels. The first level is the 17 SDGs level; while the second level is the competency level, where teachers can select the SDGs which are relevant to their courses and, then, indicate the competencies (according to the Curriculum Framework) to fit the course learning objectives. It is required that all teachers complete the online syllabus before the beginning of a semester and, thus, they are aware of the SDGs inventory module while preparing the online syllabus of their courses. Teachers are encouraged to determine whether the course content of their courses covers the topics or keywords of relevant SDGs using information from the course title, description and syllabus. Then, the teachers go through the SDGs inventory system to assign SDGs which are relevant to their courses. We believe that the course inventory is capable of facilitating the teachers to better understand how their teaching materials are associated with SDGs and promoting their awareness of SDGs, as the structuralized inventory system itself already implies an educational function of the concept of SDGs for teachers. An example of the online system is given in Figure 2. 
Syllabus

\begin{tabular}{|c|c|c|c|c|c|c|c|}
\hline Course Title (Chinese) & \multicolumn{3}{|c|}{ 給水工程 } & \multirow{2}{*}{$\begin{array}{c}\text { Course Title (English) } \\
\text { Credit }\end{array}$} & \multicolumn{3}{|c|}{ Water Supply Engineering } \\
\hline Class & A10752; & Class Code & B641 & & 3 & Type of the Course & $\begin{array}{l}\text { Environmental Engineering Professional } \\
\text {-Foundation Course }\end{array}$ \\
\hline Instructor & & 1, Hsing-lung & & $\begin{array}{c}\text { Compulsoryl } \\
\text { Elective Courses }\end{array}$ & Elective & $\begin{array}{l}\text { Course taught in } \\
\text { Languages }\end{array}$ & $\begin{array}{l}\text { Primary: Chinese } \\
\text { Secondary: English }\end{array}$ \\
\hline
\end{tabular}

This course is in the Environmental program (A) First tier, one of the most important courses in the Environmental Engineering program. This course is an up-grade version of Sanitation Engineering. This course is expected to provide students a better understanding of fundamental concepts, and the knowledge ap-grade version of Sanitation Engineesing
of design of water treatment processes.

Class Types

\begin{tabular}{|c|c|c|c|c|c|}
\hline Lectures and Discussions & $\begin{array}{c}\text { Case Study or Work } \\
\text { Analysis }\end{array}$ & $\begin{array}{c}\text { Thematic Projects and } \\
\text { Reports }\end{array}$ & $\begin{array}{c}\text { Field research/Field } \\
\text { Work }\end{array}$ & Experiment & $\begin{array}{c}\text { Others: Engineering } \\
\text { Tours }\end{array}$ \\
\hline $70 \%$ & $20 \%$ & $0 \%$ & $0 \%$ & $0 \%$ & $10 \%$ \\
\hline
\end{tabular}

\section{Course Description and Progress Outline}

Week 1 Introduction (I): Environmental Chemistry

Week 2 Introduction (II): Environmental Biology

Week 3 Introduction(III): Hydraulics and Hydrology

Week 4 Water resource and water quality

Week 5 Intake Engineering

Week 5 take Engineering

Week 6 Collection of water (I)

Week 7 Collection of water (II)

Week 8 Water pipes and
Week 9 Mid-term exam.

Week 10 Distribution of water (I)

Week 11 Distribution of water (II)

Week 12 Introduction to the unit operation of water treatment

Week 13 Sedimentation

Week 14 Coagulation and flocculation

Week 15 Filtration and backwash module dsign and practice

Week 16 Design Thinking Workshop on Urban Drainage \& Disaster Prevention (I)

Week 17 Design Thinking Workshop on Urban Drainage \& Disaster Prevention (II)

References/ Textbook/ Documen

Week 18 Final Exam.

Textbook: Water supply and pollution control, W. Viessman Jr. et. al., 2014 (8 $8^{\text {th }}$ edition)

References: Water Supply Engineering, Environmental Engineering(I): Water Supply Engineering

Participation and hand-on project 20\%, homework 30\%, midterm exam 30\%, final exam. $30 \%$

\begin{tabular}{|c|c|}
\hline \multicolumn{2}{|r|}{ UN Sustainable Development Goals (SDGs) Setting } \\
\hline Goal & Content \\
\hline 01 . No Poverty & End poverty in all its forms everywhere \\
\hline 02. Zero Hunger & End hunger, achieve food security and improved nutrition and promote sustainable agriculture \\
\hline 03. Good Health and Well-Being & Ensure healthy lives and promote well-being for all at all ages \\
\hline D 04. Quality Education & $\begin{array}{l}\text { Ensure inclusive and equitable quality education and promote lifelong learning opportunities for } \\
\text { all }\end{array}$ \\
\hline 05 . Gender Equality & Achieve gender equality and empower all women and girls \\
\hline - 06. Clean Water and Sanitation & Ensure availability and sustainable management of water and sanitation for all \\
\hline 07. Affordable and Clean Energy & Ensure access to affordable, reliable, sustainable and modem energy for all \\
\hline 08. Decent Work and Economic Growth & $\begin{array}{l}\text { Promote sustained, inclusive and sustainable economic growth, full and productive employment } \\
\text { and decent work for all }\end{array}$ \\
\hline - 09. Industry, Innovation and Infrastructure & $\begin{array}{l}\text { Build resilient infrastructure, promote inclusive and sustainable industrialization and foster } \\
\text { innovation }\end{array}$ \\
\hline 10. Reduced Inequalities & Reduce inequality within and among countries \\
\hline 11. Sustainable Cities and Communities & Make cities and human settlements inclusive, safe, resilient and sustainable \\
\hline 12. Responsible Consumption & Ensure sustainable consumption and production patterns \\
\hline 13. Climate Action & Take urgent action to combat climate change and its impacts \\
\hline 714. Life Below Water & Conserve and sustainably use the oceans, seas and marine resources for sustainable development \\
\hline 15. Life On Land & $\begin{array}{l}\text { Protect, restore and promote sustainable use of terrestrial ecosystems, sustainably manage forests, } \\
\text { combat desertification, and halt and reverse land degradation and halt biodiversity loss }\end{array}$ \\
\hline 16. Peace and Justice & $\begin{array}{l}\text { Promote peaceful and inclusive societies for sustainable development, provide access to justice for } \\
\text { all and build effective, accountable and inclusive institutions at all levels }\end{array}$ \\
\hline 17. Partnerships for the Goals & $\begin{array}{l}\text { Strengthen the means of implementation and revitalize the global partnership for sustainable } \\
\text { development }\end{array}$ \\
\hline \multicolumn{2}{|r|}{ SDG6. Clean Water and Sanitation } \\
\hline \multicolumn{2}{|c|}{$\begin{array}{l}\text {-01. Innovation in technology management, including integrated water resource management and treatment, and environmental modelling. } \\
\text {-2. Soil and water resource management practices, including improved methods for rainwater harvesting and irrigation. } \\
03 \text {. Transdisciplinary water security and research. }\end{array}$} \\
\hline \multicolumn{2}{|c|}{-04. Research on scarcity of fresh water, particularly in small island states. } \\
\hline \multirow{2}{*}{\multicolumn{2}{|c|}{-05. Governance to address water management crisis. }} \\
\hline & \\
\hline \multicolumn{2}{|l|}{-07. Sustainable water resource base. } \\
\hline \multicolumn{2}{|c|}{ - 08 . Water infrastructure resilience, water governance and adaptive management. } \\
\hline \multicolumn{2}{|c|}{$\begin{array}{l}\text {-09. Water security complexities including competing demands (e.g., human right v. commodification), transboundary management. } \\
\text {-10. Links between water resources, poverty, conflict and the economy. }\end{array}$} \\
\hline \multicolumn{2}{|c|}{$\begin{array}{l}\text {-11. Understanding of inequalities and complexities involved in water resource access and use, pollution, poverty. } \\
\text { Skills and applications }\end{array}$} \\
\hline \multicolumn{2}{|c|}{ =01. Use ICT to improve accountability of service providers. } \\
\hline \multicolumn{2}{|c|}{-02. Capacity to set up low-cost and easy-to-manage technology to address groundwater scarcity. } \\
\hline \multicolumn{2}{|l|}{-03. Implement water audits for populations to } \\
\hline \multicolumn{2}{|c|}{$\begin{array}{l}\text {-04. Develop financially sustainable models for water projects, using fees and tariff structures that reflect future costs, and manage usage while } \\
\text { subsidising water access for the poor. }\end{array}$} \\
\hline \multicolumn{2}{|c|}{ 105. Innovation in technology and governance for sustainable water management. } \\
\hline \multicolumn{2}{|c|}{-06. Water demand analysis and management, water demand modelling, water distribution systems analy } \\
\hline \multicolumn{2}{|c|}{-07. Develop and implement water-related climate change mitigation and adaptation strategies. } \\
\hline \multirow{2}{*}{\multicolumn{2}{|c|}{$\begin{array}{l}\text {-08. Applied research to promote access to clean water and sanitation in resource-poor areas. } \\
\text { Values and attitudes }\end{array}$}} \\
\hline & \\
\hline \multicolumn{2}{|l|}{$\begin{array}{l}\text {-01. Committed to reducing the } \\
\text { and reducing emissions. }\end{array}$} \\
\hline \multicolumn{2}{|c|}{ =02. Make professional contributions to societal transformation. } \\
\hline \multicolumn{2}{|l|}{ - 03 . Raise awareness of current water crises. } \\
\hline \multicolumn{2}{|l|}{-04. Reduce water usage and avoid releasing effluent. } \\
\hline $\begin{array}{l}\text {-05. Solution-minded approach to sustainable wa } \\
\text {-06. Valuing water and sanitation as a human rig }\end{array}$ & ter use and ecosystem health. \\
\hline
\end{tabular}

Figure 2. Form (originally in Chinese) designed in the online curriculum system embedded with a sustainable development goals (SDGs) inventory module [29]. 


\subsection{Data Analysis}

Data including three consecutive semesters was collected from the fall semester of 2018 to the fall semester of 2019. The numbers of full-time faculty members and adjunct faculty members were approximately 225 and 120, respectively. We encouraged all teachers to participate in the SDGs inventory and there were 229, 220 and 289 teachers responding to the inventory within these three semesters, respectively. The number of courses analyzed in this study were 1292 in the fall semester of 2018, 1202 in the spring semester of 2019 and 1235 in the fall semester of 2019. The percentage of courses identified to be related to SDGs was $55 \%$ in the fall semester of $2018,51 \%$ in the spring semester of 2019 and $65 \%$ in the fall semester of 2019. Table 1, which summarizes the total course offerings and courses related to SDGs from each department among the five colleges and General Education Center, provides critical information to understand the distribution of SDGs-related courses at different levels and to determine the most relevant SDGs with respect to different colleges. Detailed inventory results for the fall semester of 2018 are given in Table S1. It should be noted that the SDGs-related courses may cover more than one SDG per course in the inventory, but users are recommended to assign no more than three SDGs in their courses (based on the instructions of our inventory system).

To better elucidate our data, a virtualization treatment of data was further applied to examine the interdisciplinarity analysis measured by diversity of SDGs. In order to achieve this, we used the results of Table S1, which include the data of subtotal for each college and total for the whole university, to calculate the weighting of each SDG with respect to all SDGs in terms of numbers for colleges and whole university. The weighting reflects the focus of the specific SDG across the colleges and university among the 17 SDGs.

For each unit, the weighting of a specific SDG is given by:

$$
\text { SDG X }=\left[\frac{\text { The total number of a specific SDG X from SDGs-related course of ferings in a unit }}{\text { The total number of ALL SDGs from SDGs-related course of ferings in a unit }}\right] \times 100 \% \text {. }
$$

Equation (1) represents the ratio of the total number of a specific SDG to that of all SDGs from SDGs-related course offerings in each unit, which refers to either the college or university level. For example, the total number of SDG 1 (no poverty) and that of all SDGs collected from the General Education Center course offerings were 22 and 318, respectively (Table S1). Thus, the weighting of SDG 1-related courses offered by the General Education Center was $6.9 \%$. Table S2 summarizes each specific SDG weighting in all SDGs-related courses among the different colleges at NUK. 
Table 1. Number of total course offerings and the number of courses related to sustainable development goals (SDGs) from each department.

\begin{tabular}{|c|c|c|c|c|c|c|c|}
\hline \multirow{2}{*}{$\begin{array}{l}\text { Academic } \\
\text { Division }\end{array}$} & \multirow{2}{*}{ Department } & \multicolumn{2}{|c|}{ Fall 2018} & \multicolumn{2}{|c|}{ Spring 2019} & \multicolumn{2}{|c|}{ Fall 2019} \\
\hline & & Total COURSES & $\begin{array}{c}\text { Courses Related } \\
\text { to SDGs }\end{array}$ & Total Courses & $\begin{array}{l}\text { Courses Related } \\
\text { to SDGs }\end{array}$ & Total Courses & $\begin{array}{c}\text { Courses Related } \\
\text { to SDGs }\end{array}$ \\
\hline \multirow{8}{*}{$\begin{array}{l}\text { General Education } \\
\text { Center }\end{array}$} & Common Compulsory Curriculum & 173 & 57 & 170 & 52 & 170 & 63 \\
\hline & Humanities & 30 & 20 & 33 & 19 & 33 & 24 \\
\hline & Natural Sciences & 25 & 18 & 24 & 13 & 24 & 16 \\
\hline & Social Science & 36 & 21 & 27 & 19 & 36 & 29 \\
\hline & General Microcredit courses & 10 & 7 & 6 & 6 & 18 & 14 \\
\hline & Core Curriculum & 41 & 24 & 40 & 30 & 34 & 29 \\
\hline & Electives by Interest & 3 & 2 & 2 & 2 & 2 & 2 \\
\hline & Sub-Total & 318 & 149 & 302 & 141 & 317 & 177 \\
\hline \multirow{9}{*}{$\begin{array}{c}\text { College of } \\
\text { Humanities and } \\
\text { Social Sciences }\end{array}$} & Common Learnings & 11 & 5 & 1 & 1 & 11 & 7 \\
\hline & Dept. of Crafts and Creative Design & 8 & 5 & 10 & 5 & 18 & 8 \\
\hline & $\begin{array}{l}\text { Dept. of Kinesiology, Health and } \\
\text { Leisure Studies }\end{array}$ & 55 & 44 & 52 & 37 & 51 & 42 \\
\hline & Dept. of Athletic Performance & 40 & 10 & 42 & 16 & 42 & 18 \\
\hline & $\begin{array}{c}\text { Dept. of Western Languages and } \\
\text { Literature }\end{array}$ & 39 & 15 & 36 & 11 & 34 & 22 \\
\hline & $\begin{array}{c}\text { Dept. of East Asian Languages and } \\
\text { Literature }\end{array}$ & 60 & 37 & 50 & 26 & 52 & 31 \\
\hline & $\begin{array}{c}\text { Dept. of Creative Design and } \\
\text { Architecture }\end{array}$ & 46 & 28 & 40 & 22 & 25 & 17 \\
\hline & Dept. of Architecture & 15 & 5 & 17 & 6 & 27 & 14 \\
\hline & Sub-Total & 274 & 149 & 248 & 124 & 260 & 159 \\
\hline
\end{tabular}


Table 1. Cont.

\begin{tabular}{|c|c|c|c|c|c|c|c|}
\hline \multirow{2}{*}{$\begin{array}{c}\text { Academic } \\
\text { Division }\end{array}$} & \multirow{2}{*}{ Department } & \multicolumn{2}{|c|}{ Fall 2018} & \multicolumn{2}{|c|}{ Spring 2019} & \multicolumn{2}{|c|}{ Fall 2019} \\
\hline & & Total COURSES & $\begin{array}{l}\text { Courses Related } \\
\text { to SDGs }\end{array}$ & Total Courses & $\begin{array}{l}\text { Courses Related } \\
\text { to SDGs }\end{array}$ & Total Courses & $\begin{array}{l}\text { Courses Related } \\
\text { to SDGs }\end{array}$ \\
\hline \multirow{4}{*}{ College of Law } & Dept. of Law & 55 & 34 & 60 & 39 & 58 & 49 \\
\hline & Dept. of Government and Law & 61 & 5 & 52 & 2 & 57 & 7 \\
\hline & Dept. of Economic and Financial Law & 55 & 39 & 45 & 31 & 48 & 35 \\
\hline & Sub-Total & 171 & 78 & 157 & 72 & 163 & 91 \\
\hline \multirow{7}{*}{$\begin{array}{l}\text { College of } \\
\text { Management }\end{array}$} & Common Learnings & 3 & 1 & 3 & 1 & 3 & 2 \\
\hline & $\begin{array}{l}\text { Dept. of Asia Pacific Industrial and } \\
\text { Business Management }\end{array}$ & 47 & 21 & 39 & 19 & 36 & 28 \\
\hline & Dept. of Finance & 33 & 20 & 31 & 25 & 32 & 21 \\
\hline & $\begin{array}{c}\text { International Master of Business } \\
\text { Administration }\end{array}$ & 11 & 4 & 10 & 8 & 10 & 10 \\
\hline & Dept. of Information Management & 37 & 18 & 33 & 22 & 41 & 35 \\
\hline & Dept. of Applied Economics & 32 & 23 & 27 & 15 & 28 & 20 \\
\hline & Sub-Total & 163 & 87 & 143 & 90 & 150 & 116 \\
\hline \multirow{7}{*}{ College of Science } & Common Learnings & 5 & 2 & 4 & 3 & 2 & 2 \\
\hline & Dept. of Applied Chemistry & 36 & 19 & 34 & 17 & 32 & 22 \\
\hline & Dept. of Applied Physics & 36 & 23 & 31 & 19 & 34 & 20 \\
\hline & Dept. of Applied Mathematics & 34 & 27 & 36 & 11 & 35 & 18 \\
\hline & Dept. of Life Sciences & 45 & 31 & 37 & 22 & 43 & 39 \\
\hline & Institute of Statistics & 12 & 5 & 10 & 3 & 10 & 4 \\
\hline & Sub-Total & 168 & 107 & 152 & 75 & 156 & 105 \\
\hline
\end{tabular}


Table 1. Cont

\begin{tabular}{|c|c|c|c|c|c|c|c|}
\hline \multirow{2}{*}{$\begin{array}{l}\text { Academic } \\
\text { Division }\end{array}$} & \multirow{2}{*}{ Department } & \multicolumn{2}{|c|}{ Fall 2018} & \multicolumn{2}{|c|}{ Spring 2019} & \multicolumn{2}{|c|}{ Fall 2019} \\
\hline & & Total COURSES & $\begin{array}{c}\text { Courses Related } \\
\text { to SDGs }\end{array}$ & Total Courses & $\begin{array}{c}\text { Courses Related } \\
\text { to SDGs }\end{array}$ & Total Courses & $\begin{array}{c}\text { Courses Related } \\
\text { to SDGs }\end{array}$ \\
\hline \multirow{6}{*}{$\begin{array}{l}\text { College of } \\
\text { Engineering }\end{array}$} & $\begin{array}{l}\text { Dept. of Civil and Environmental } \\
\text { Engineering }\end{array}$ & 38 & 31 & 42 & 27 & 48 & 42 \\
\hline & $\begin{array}{l}\text { Dept. of Chemical and Materials } \\
\text { Engineering }\end{array}$ & 35 & 22 & 35 & 14 & 31 & 27 \\
\hline & $\begin{array}{l}\text { Dept. of Computer Science and } \\
\text { Information Engineering }\end{array}$ & 47 & 31 & 48 & 34 & 34 & 25 \\
\hline & Dept. of Electrical Engineering & 78 & 54 & 75 & 37 & 76 & 63 \\
\hline & Sub-Total & 198 & 138 & 200 & 112 & 189 & 157 \\
\hline & Total & 1292 & 708 & 1202 & 614 & 1235 & 805 \\
\hline
\end{tabular}




\section{Results}

\subsection{University Level}

As shown in Figure 3, it is evident that SDG 3 (good health and well-being), SDG 4 (quality education), SDG 8 (decent work and economic growth), SDG 9 (industry, innovation and infrastructure) and SDG 16 (peace, justice and strong institutions) were the relatively significant Goals related to the course offerings at NUK; especially SDGs 4, 8 and 9. For instance, with a total of 1292 courses, 708 courses were indicated to link SDGs in the fall semester of 2018. Among them, SDG 4 (quality education; 34.1\%), SDG 8 (decent work and economic growth; 33.0\%) and SDG 9 (industry, innovation and infrastructure; $28.9 \%$ ) were prioritized to be the most relevant. A relatively stable pattern of the curriculum structure for SDGs-related courses can be observed throughout the three semesters. The course inventory mapping provides a convenient university-wide overview of the profiles and prioritizations of each HEI. Though the comparison of sustainability course inventory results with different self-reporting HEIs is difficult, it is worth pointing out that SDG 3 (good health and well-being), SDG 5 (gender equality), SDG 13 (climate action) and SDG 16 (peace, justice and strong institutions) were found to be the major SDGs covered by the sustainability courses at the University of Toronto [24]. From a practical point of view, considering the behavioral change of individuals is a key to trigger the sustainability in higher education, Sonetti et al. recommended four practicable SDGs, namely, SDG 4 (quality education), SDG 17 (partnerships for the goals), SDG 12 (responsible consumption and production) and SDG 13 (climate action) for implementation in HEIs [4].

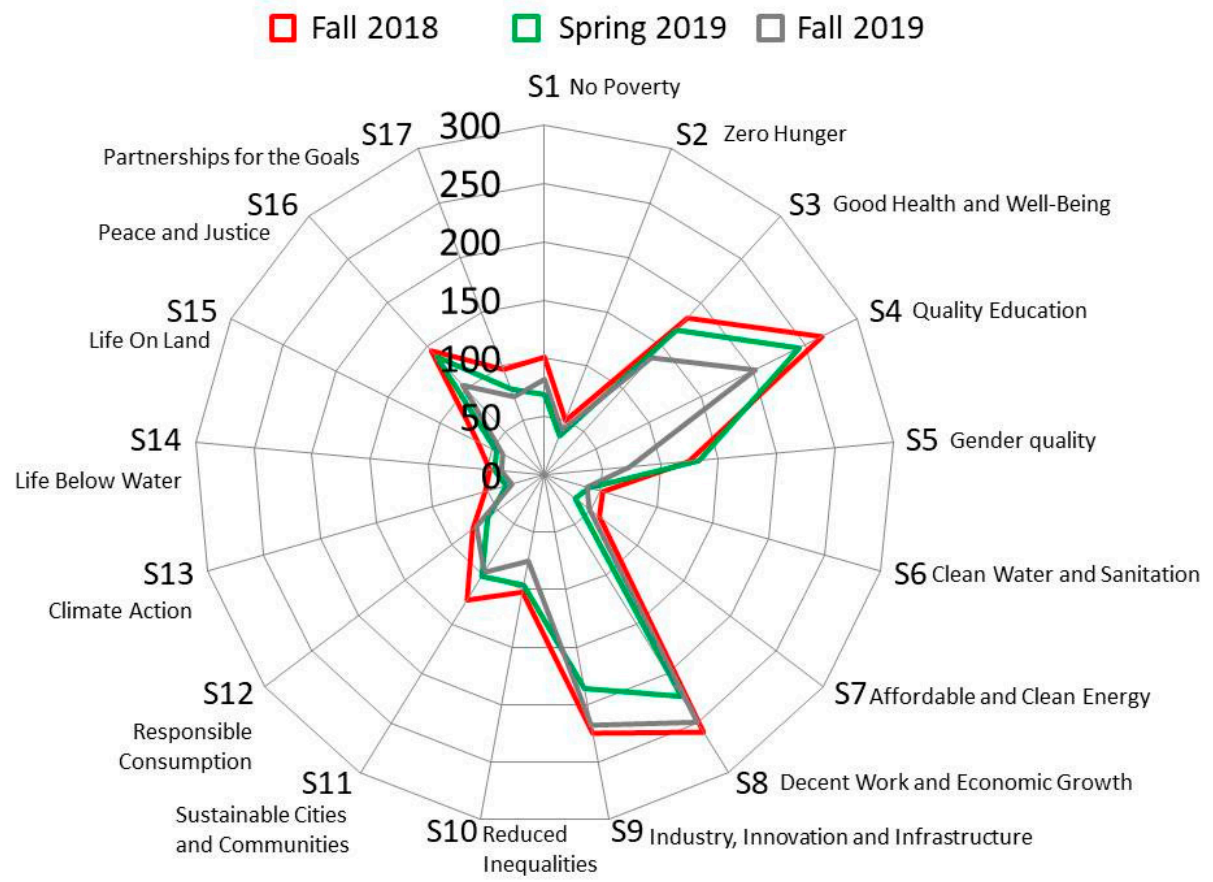

Figure 3. Distribution of SDGs-related courses in the whole university within three consecutive semesters. Numbers are the total courses corresponded to each specific SDG (denoted as S).

\subsection{College Level}

At the college level, as shown in Figure 4, both the College of Humanities and Social Sciences and the General Education Center indicated that SDG 4 (quality education) was the one fitted to the most of SDGs-related courses. The courses offered by the College of Engineering and the College of Management were more related to SDG 9 (industry, innovation and infrastructure) and SDG 8 (decent work and economic growth), respectively. The College of Law emphasized SDG 16 (peace, justice and strong institutions). Even though a relatively lesser amount of data was received, the College of 
Science was similar to the College of Engineering, also focusing on SDG 9 (industry, innovation and infrastructure). Table 2 summarizes the three most related-SDGs with respect to different colleges for the three semesters at NUK, from which more detailed information can be observed. For example, SDG 8 and SDG 9 were the major Goals for the College of Management, the College of Science and the College of Engineering, while SDG 11 (sustainable cities and communities) was also a key attribute in the College of Engineering. It can be seen that the colleges with expertise in particular subject areas related to specific SDGs had a strong tendency to offer more courses with a primary or explicit focus on specific SDGs. This is consistent with the study of Brugmann et al. where SDG 9 (industry, innovation and infrastructure) was shown to be a major focus of sustainability courses for the Faculty of Applied Science and Engineering at the University of Toronto [26]. However, the 3rd most relevant SDG was different in the College of Humanities and Social Sciences and the College of Law depending on semester, suggesting that either courses had changed from one semester to another or that teachers had altered their selection of SDGs while filling out the inventory form. The benefit of the course inventory is to provide a metric to track changes in the amount of focus on sustainability in the curriculum across the university $[26,38]$.

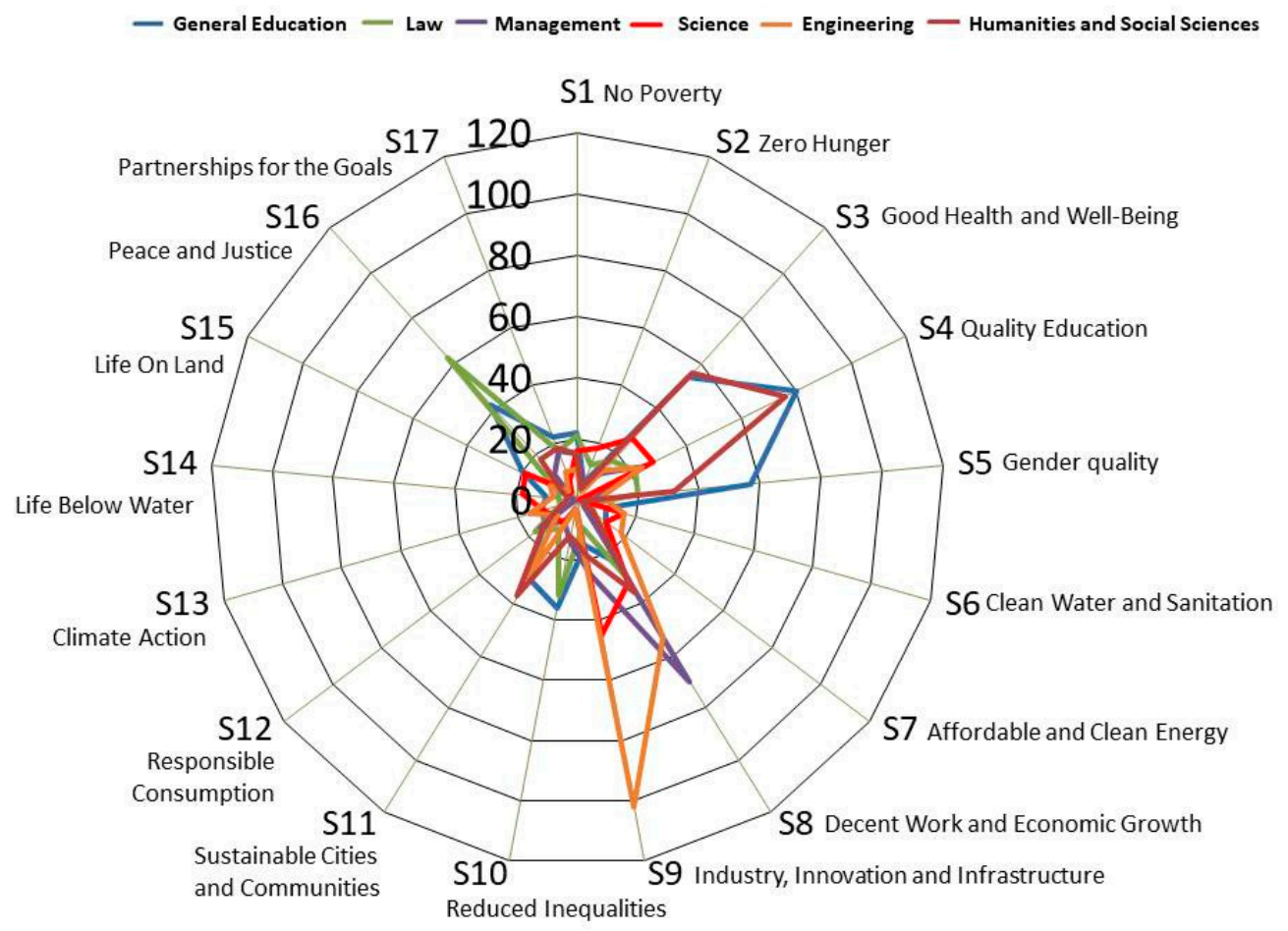

Figure 4. Distribution of SDGs-related courses in the different colleges. Numbers are the total courses corresponding to each specific SDG (denoted as S). Data presented is from the fall semester of 2018. 
Table 2. Three most relevant SDGs with respect to different colleges for the three semesters at the National University of Kaohsiung (NUK).

\begin{tabular}{|c|c|c|c|c|c|c|c|c|c|}
\hline \multirow[b]{2}{*}{ Academic Division } & \multicolumn{3}{|c|}{ Fall 2018} & \multicolumn{3}{|c|}{ Spring 2019} & \multicolumn{3}{|c|}{ Fall 2019} \\
\hline & $\begin{array}{c}\text { The 1st } \\
\text { Relevant } \\
\text { SDG }\end{array}$ & $\begin{array}{l}\text { The 2nd } \\
\text { Relevant } \\
\text { SDG }\end{array}$ & $\begin{array}{l}\text { The 3rd } \\
\text { Relevant } \\
\text { SDG }\end{array}$ & $\begin{array}{c}\text { The 1st } \\
\text { Relevant } \\
\text { SDG }\end{array}$ & $\begin{array}{l}\text { The 2nd } \\
\text { Relevant } \\
\text { SDG }\end{array}$ & $\begin{array}{c}\text { The 3rd } \\
\text { Relevant } \\
\text { SDG }\end{array}$ & $\begin{array}{c}\text { The 1st } \\
\text { Relevant } \\
\text { SDG }\end{array}$ & $\begin{array}{c}\text { The 2nd } \\
\text { Relevant } \\
\text { SDG }\end{array}$ & $\begin{array}{c}\text { The 3rd } \\
\text { Relevan } \\
\text { SDG }\end{array}$ \\
\hline General Education Center & 4 & 5 & 3 & 4 & 3 & 5 & 4 & 3 & 5 \\
\hline $\begin{array}{l}\text { College of Humanities and } \\
\text { Social Sciences }\end{array}$ & 4 & 3 & 8 & 3 & 4 & 5 & 4 & 3 & 11 \\
\hline College of Law & 16 & 10 & 8 & 16 & 4 & 5 & 16 & 10 & 1 \\
\hline College of Management & 8 & 9 & 4 & 8 & 4 & 9 & 8 & 9 & 4 \\
\hline College of Science & 9 & 8 & 4 & 9 & 4 & 8 & 9 & 8 & 4 \\
\hline College of Engineering & 9 & 8 & 11 & 9 & 8 & 11 & 9 & 8 & 11 \\
\hline
\end{tabular}




\subsection{Department Level}

At a department level, certain SDGs by subject areas were clearly aligned with specific departments in our university. As listed in Table 3, all 17 SDGs were used to map the course sustainability and find the first and second most relevant departments in the fall semester of 2019. Again, similar to the findings we observed at the college level, the relationships between the particular subject areas of the department and the attribute of a specific SDG becomes more apparent. For example, SDG 6 (clean water and sanitation) is highly related to the expertise of the Department of Civil and Environmental Engineering. Among the total of 48 courses offered, it was reported that 16 courses had sustainability content related to SDG 6 (Table 3). Analogously, SDG 14 (life below water) and SDG 15 (life on land) were strongly tied to the Department of Life Science.

Table 3. Departments offering the most abundant SDGs-related courses with respect to each specific SDG.

\begin{tabular}{|c|c|c|c|}
\hline SDGs & & $\begin{array}{c}\text { The First Most Relevant } \\
\text { Department }\end{array}$ & The Second Most Relevant Department \\
\hline SDG 1 & No Poverty & Life Science (9/43) & General Education (9/317) \\
\hline SDG 2 & Zero Hunger & Life Science (11/43) & General Education (4/317) \\
\hline SDG 3 & Good Health and Well-Being & $\begin{array}{l}\text { Kinesiology, Health and Leisure } \\
\text { Studies (32/51) }\end{array}$ & General Education (32/317) \\
\hline SDG 4 & Quality Education & General Education (40/317) & East Asian Languages and Literature (27/52) \\
\hline SDG 5 & Gender Equality & General Education (68/317) & Western Languages and Literature (10/34) \\
\hline SDG 6 & Clean Water and Sanitation & Civil \& Environ. Eng. (16/48) & Applied Chemistry $(8 / 32)$ \\
\hline SDG 7 & Affordable and Clean Energy & Electrical Eng. (13/76) & Applied Chemistry (8/32) \\
\hline SDG 8 & $\begin{array}{c}\text { Decent Work and Economic } \\
\text { Growth }\end{array}$ & Electrical Eng. (32/76) & $\begin{array}{l}\text { Asia Pacific Industrial and Business } \\
\text { Management (20/36); Finance (20/32) }\end{array}$ \\
\hline SDG 9 & $\begin{array}{l}\text { Industry, Innovation and } \\
\text { Infrastructure }\end{array}$ & Electrical Eng. (47/76) & $\begin{array}{c}\text { Computer Science and Information } \\
\text { Engineering }(21 / 34)\end{array}$ \\
\hline $\begin{array}{l}\text { SDG } \\
10\end{array}$ & Reduced Inequalities & General Education (28/317) & Law $(13 / 58)$ \\
\hline $\begin{array}{c}\text { SDG } \\
11\end{array}$ & $\begin{array}{l}\text { Sustainable Cities and } \\
\text { Communities }\end{array}$ & Civil \& Environ. Eng. (27/48) & General Education (17/317) \\
\hline $\begin{array}{l}\text { SDG } \\
12\end{array}$ & Responsible Consumption & $\begin{array}{l}\text { Asia Pacific Industrial and } \\
\text { Business Management (10/36) }\end{array}$ & Law $(8 / 58)$ \\
\hline $\begin{array}{l}\text { SDG } \\
13\end{array}$ & Climate Action & Civil \& Environ. Eng. (7/48) & Applied Chemistry (5/36) \\
\hline $\begin{array}{l}\text { SDG } \\
14\end{array}$ & Life Below Water & Life Science (18/35) & Civil \& Environ. Eng. (7/348) \\
\hline $\begin{array}{l}\text { SDG } \\
15\end{array}$ & Life On Land & Life Science $(19 / 35)$ & Civil \& Environ. Eng. (9/48) \\
\hline $\begin{array}{l}\text { SDG } \\
16\end{array}$ & Peace and Justice & Law $(40 / 58)$ & Economic \& Financial Law (28/48) \\
\hline $\begin{array}{c}\text { SDG } \\
17\end{array}$ & Partnerships for the Goals & Law $(10 / 58)$ & General Education (10/317) \\
\hline
\end{tabular}

Note: Numbers in parentheses represents the total number of courses with the specific SDG vs the total number of courses offered by the department. Data presented are from the fall semester of 2019.

Even though the most relevant department offered the highest SDGs-related courses with respect to a specific SDG, the weighting of the specific SDGs-related courses was scattered widely across the university. For the most relevant department shown in Table 3, the Department of Law showed the highest percentage of SDGs-related courses linked with SDG 16 (peace, justice and strong institutions; 69.0\%), while the Department of Civil and Environmental Engineering exhibited the highest percentage of SDGs-related courses linked with SDG 13 (climate action; 14.5\%). However, SDG 13 of all SDGs-related courses accounted for the lowest percentage among all the SDGs. It is no surprise to observe these results; yet, we learn that, even if a department provides the largest number of courses related to a specific SDG in the university, it does not ensure that the department is well-prepared for that particular SDG, if the curriculum is still based on a traditional silo disciplinary structure. As a quantitative study, it is capable of unveiling the emerging issue that has not yet been noted. One typical example is the Department of Civil and Environmental Engineering, which offers the largest number of courses (7 out of 48) related to SDG 13 (climate action). However, the courses are far behind the need, regardless of quantities and quality; thus, enrichment of the course content, 
with more focus on SDGs to enhance the quality, is required. In fact, a further in-depth qualitative study, such as an interview with stakeholders, is needed. As mentioned above, sustainable transitions require the essential transformation of the curriculum framework towards sustainability $[12,14]$. Thus, the transformation of Civil and Environmental Engineering towards Sustainable Engineering is strongly recommended to fulfill the needs of future generations, when the significance and impact of global climate change are taken into consideration.

\subsection{The Diversity of SDGs in SDGs-related Courses}

The radar chart shown in Figure 4 points out which SDGs are the major elements in different colleges. Figure 5, on the other hand, depicts the "diversity" of various SDGs in our university, at the college level, in the fall semester of 2018. The spectrum chart illustrated in Figure 5 consists of the 119 data points listed in Table S2, which were calculated by Equation (1) using the raw data in Table S1. A five-level color scale bar for each specific SDG was constructed for Figure 5. For example, in the case of SDG 1 (no poverty), the highest and lowest percentages were contributed by the College of Law $(6.61 \%)$ and College of Engineering (2.45\%), respectively (Table S2). Thus, the five-level color scale bar was equally divided by 5 from $6.61 \%$ to $2.45 \%$, where a darker color indicates a higher percentage of SDGs. As shown in Figure 5, each SDG has its own color, designated by the official SDG color code, with a specific scale bar. Therefore, the focus of a specific SDG among the colleges can easily be identified column-wise, while the diversity of SDGs for each college can be revealed row-wise.

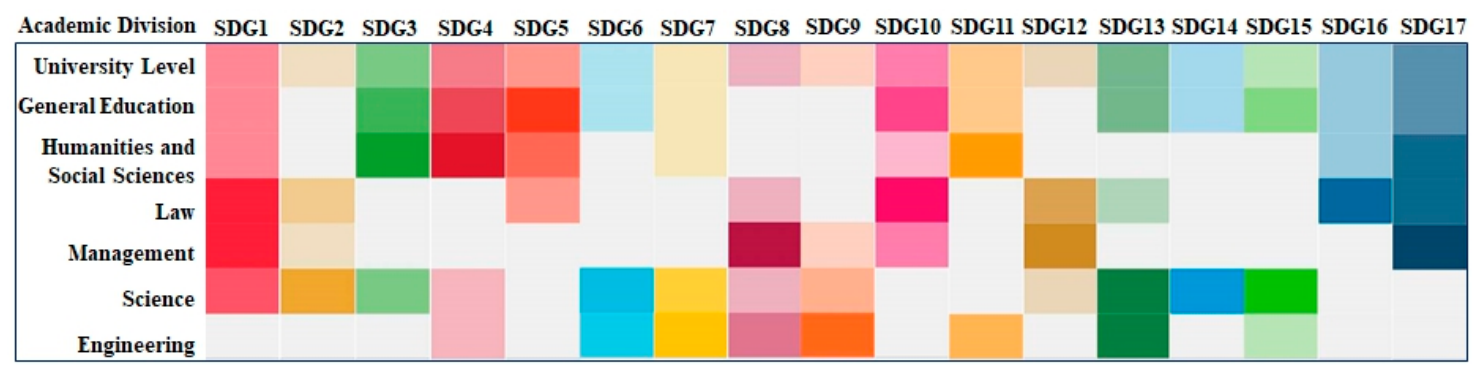

Figure 5. Spectrum chart of the SDG diversity of all SDGs-related courses in the college level.

Differing from Figure 5, we interpreted our SDG data in a different perspective, in order to gain insight into the whole university, by using a single color bar. The same data applied in Figure 5 was used for visualization, as shown in Figure 6, where we selected the highest and lowest percentage of all SDGs from all 119 data points shown in Table S2 to create the 5-level scale bar. In other words, there is only one scale bar utilized in Figure 6, where the range of the scale bar is from 31.5\% to $0.60 \%$ and is equally divided by 5 . The darkest color is SDG 9 (industry, innovation and infrastructure) for the College of Engineering, indicating the highest percentage of all SDGs (31.5\%); while the lightest color was SDG 6 (clean water and sanitation) for the College of Humanities and Social Sciences $(0.60 \%)$. As shown in Figure 6, it is clear that the curriculum of our university mainly emphasizes SDG 4 (quality education), SDG 8 (decent work and economic growth), SDG 9 (industry, innovation and infrastructure) and SDG 16 (peace, justice and strong institutions). More important, Figure 6 reveals where we are insufficient, rather than just our existing strengths. The spectrum indicates the many SDGs are still lacking in all colleges, including SDG 1 (no poverty), SDG 2 (zero hunger), SDG 6 (clean water and sanitation), SDG 7 (affordable and clean energy), SDG 12 (responsible consumption and production), SDG 13 (climate action), SDG 14 (life below water), SDG 15 (life on land) and SDG 17 (partnerships for the goals); even though we have specific departments engaging those SDGs. This suggests that SDGs-related courses are far from sufficient at NUK. 


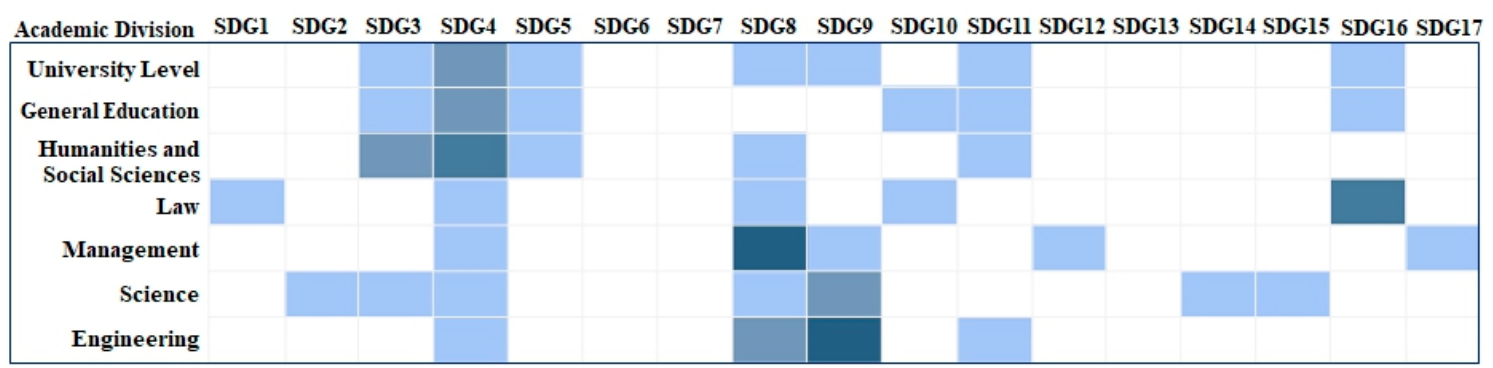

Figure 6. Spectrum chart of the SDG diversity for all the SDGs-related courses in the university level.

\section{Discussion}

Similar to many other HEIs having challenges with integrating sustainability into their institutional systems $[17,18]$, we observed faculty members lacking awareness and concern for sustainability are an obstacle to sustainability transitions at NUK. Thus, an attempt was made to promote their awareness of SDGs by implementing a SDG course inventory system by the academic administration of NUK. In this work, we present the results of the SDG course inventory system, which helps to understand the baseline status of sustainability through the distribution of SDGs-related courses at different levels in the overall university curriculum. From the baseline status, it was found that the average number of SDGs linked to a course was about 2.65 throughout the whole university. The course offerings of the College of Law showed the highest number of SDGs per course (3.25, on average); while those offered by the College of Engineering showed the lowest number of SDGs per course (2.28). According to the study conducted by Brugmann et al., the number of SDGs covered by a course was considered to be indicative of the degree of sustainability focus in the course while they investigated the use of their sustainability course inventories at the University of Toronto [26]. Our study suggests that the number of SDGs covered by a course reflects the diversity of the sustainability topics covered in the course. As shown in Figures 5 and 6, the method used here does give an indication of the areas covered and, thus, also points to blind spots with insufficient coverage of SDGs. Moreover, it can also give an indication of the diversity within colleges, which could suggest future paths for transdisciplinary development and capacity-building at the university level.

As sustainability is highly inter- and trans-disciplinary $[39,40]$, the collaboration of faculty members from different disciplines is essential for sustainability transitions in the university where we observed the difficulty of faculty members to find partners for collaborating with SDGs into teaching and research at NUK. This obstacle has also been reported as we mentioned previously when integrating sustainability into higher education $[17,21]$. The SDG course inventory can, therefore, serve as a fast scanning system to identify the hot spots and blind spots, reflecting the strengths and weaknesses with respect to specific SDGs for each unit. The hot spots shown in Figure 5 provide the academic administration with useful information to better understand the interdisciplinary capacity of faculty members in pursuing SDGs and to identify internal collaboration opportunities in the university. For example, both the College of Law and the College of Management showed a strong emphasis on SDG 1 (no poverty; dark red in SDG 1 column in Figure 5). Thus, there is an opportunity for both colleges to use SDG 1 (no poverty) as a platform to collaborate in developing new interdisciplinary programs based on their advantages. Further, a synergy effect may be developed through cross-disciplinary collaboration, which is no longer limited to a specific SDG, leading to the overall transformation of the curriculum. Indeed, education for sustainable development requires the participation of interdisciplinarity and collaboration with various non-academic sectors [41,42]. Previous studies have revealed that university students generally do not know the SDGs, as they require a wide variety of both specific and transversal competences in courses [43]. Consequently, better integration of topics related to the SDGs in teaching programs is essential to creating SDG literacy [13]. 
As shown in Figure 5, the university level is the overall status of the SDG distribution, which can be referred to as the "average state". In general, the college level shows that each college has its own strengths and weakness associated with various SDGs, depending on its expertise. Figure 5 also reveals that the course structure pattern of the General Education Center, in terms of sustainability content, exhibits similarity to that of the whole university. Only SDG 2 (zero hunger), SDG 8 (decent work and economic growth), SDG 9 (industry, innovation and infrastructure) and SDG 12 (responsible consumption and production) were lesser than those of the university, in terms of percentage of corresponding SDGs-related course ratio (Equation (1)). Surprisingly, the College of Science showed a spectrum covering more SDGs than we expected. Only SDG 5 (gender equality), SDG 10 (reduce inequality), SDG 11 (sustainable cities and communities), SDG 16 (peace, justice and strong institutions) and SDG 17 (partnerships for the goals) were lesser than those of the university. According to the results at college level, it may be further categorized by two patterns: The first pattern is the college course offerings linked to a wide variety of SDGs; while the second pattern is the college course offerings linked only to a specific SDG related to the subject areas of the college. The results suggest that the General Education Center and the College of Science, which are more likely to fit into the first pattern, offer more diversified courses which cover more SDGs at the college level. On the other hand, the remaining four colleges belong to the second pattern. They show a relatively narrow SDGs spectrum, indicating that their curriculum framework is mainly focused on specific SDGs.

The above-mentioned discussion leads us to raise the following question "Is there any so-called "best" pattern of curriculum framework existing for the university when SDGs are taken into consideration?" As mentioned before, the college course offerings related to SDGs may have two patterns. Ideally, if universities have abundant resources, they may choose the first pattern to provide sufficient and nearly equal amounts of courses with respect to all SDGs. On the other hand, there is another strategy: for the university to use the second pattern based on colleges with solid academics. However, with this strategy, it is inevitable to find lacking SDGs which need to be complemented. Clearly, no single HEI can offer high-quality and in-depth education in all areas. At national and regional levels, it is therefore important to ensure co-ordination between HEIs, such that their different profiles complement each other.

Studies conducted by Zamora-Polo et al. pointed out that both specific and transversal competences are required for educating students to understand SDGs [43]. They suggested that transversal competences related to SDGs or sustainability should be permeated into all subjects, from basic courses to more specific courses in universities [43]. The immersion of transversal competences into courses may help to complement the needs of the second pattern (i.e., the course offerings emphasize specific SDGs in particular subject areas), even though the transversal competences alone are not be able to ensure that a country or region actually have access to research and professional competence covering all of the SDGs. Furthermore, our opinion is that the general education may play a role to support the needs of providing transversal competences into the courses, in order to compensate for the lack of holistic understanding and systems thinking. In the case of NUK, however, the courses offered by the General Education Center show a similar SDGs pattern to those offered by the university, which does not complement the needs of university. We believe that the General Education Center of NUK should reform its curriculum framework to fulfill the SDGs-Inside policy of NUK. Under limited resources, we suggest that the university may choose the strategy where professionally oriented colleges complement general education to achieve the maximum SDG coverage to which the courses are linked.

At the department level, this study offers evidence-based practice for departments to reform their curriculum by integrating SDGs. From the SDG course inventory, departments may review their curriculum structure regularly and allocate resources into their target SDGs. It is likely that the current curriculum framework of a given department is based on the guidance of traditional discipline structures, which are mainly professionally oriented in the syllabus design. To accelerate the reform of the curriculum, support from a top-down university policy of sustainability, resource support for teachers to redesign courses, and an enhancement of the awareness of teachers are needed. 


\section{Limitations of the Study}

The case study was based on the university-wide data of SDGs-related courses collected from the SDGs course inventory system at NUK. A quantitative analysis was conducted to interpret the results. However, certain limitations can be found in the study. Though many case studies have reported the use of SDGs as indicators to evaluate curricula with respect to the degree of sustainability [24-27], there are difficulties in comparing the sustainability course inventory results with different self-reporting HEIs. More homogenization is needed among countries or regions. Furthermore, to initiate curriculum reform at both university and department levels, quantitative analysis of the course inventory alone, serving as a fast scanning system to identify the weaknesses and strengths of the units with respect to the degree of sustainability in their curriculum, is not sufficient to complete the task. It must be coupled with in-depth qualitative studies of the courses offered, such that the department may redesign the curriculum to reflect how the reformed curriculum relates both to the department and to societal needs. Nevertheless, our virtualization method, which maps course sustainability by the SDG diversity, is applicable to all universities who wish to find their hot spots and blind spots for various SDGs, as long as they can collect university-wide data using SDGs as indicators in their course inventory.

\section{Conclusions}

The online curriculum system embedded with the SDGs course inventory module provides significant benefits to NUK. First, to facilitate the better understanding of faculty members in how their teaching materials are associated with SDGs and to promote their awareness of SDGs. Second, to instruct students with respect to the relationship between their learning content and the SDGs. Finally, to help universities gain a baseline status of sustainability in their curriculum, such that they may plan their strategy for sustainability and prioritize the allocation of resources accordingly. The specific findings are concluded below:

- Our study suggests that the number of SDGs covered by a course reflects the diversity of the sustainability topics covered in the course. This metric gives an indication of the areas covered and, thus, also point to blind spots. Moreover, it can also give an indication of the diversity within colleges, which could suggest future paths for transdisciplinary development;

- It is evident that the curriculum of our university mainly emphasizes SDG 3 (good health and well-being), SDG 4 (quality education), SDG 8 (decent work and economic growth), SDG 9 (industry, innovation and infrastructure) and SDG 16 (peace, justice and strong institutions). However, our study indicated that many SDGs are still not focused in all colleges;

- The SDGs course inventory offers the academic administration useful information, in order to better understand the interdisciplinary capacity and internal collaboration opportunities in the university;

- SDGs can serve as a platform to develop innovative and interdisciplinary programs through the collaboration of various colleges, where their faculty members may engage with the same SDGs through different approaches;

- Certain SDGs are clearly aligned with the expertise of specific departments in our university. However, we found that, even if a department provides the largest number of courses related to a specific SDG in the university, it does not necessarily ensure that the department is well-prepared for that particular SDG. In-depth qualitative studies, such as an interview with stakeholders, are needed. This study offers evidence-based practice for departments to reform their curricula by integrating SDGs;

- General education may play an important role in supporting the needs of providing transversal competences into courses, in order to compensate for the lack of holistic understanding and systems thinking when sustainability is integrated into the overall university curriculum. 
Supplementary Materials: The following are available online at http://www.mdpi.com/2071-1050/12/10/4274/s1, Table S1: SDGs-related course inventory results for the fall semester of 2018; Table S2: The raw data for the preparation of Figures 5 and 6.

Author Contributions: Conceptualization, Y.-C.C. and H.-L.L.; methodology, Y.-C.C. and H.-L.L.; software, Y.-C.C. and H.-L.L.; validation, Y.-C.C. and H.-L.L.; formal analysis, Y.-C.C. and H.-L.L.; investigation, Y.-C.C. and H.-L.L.; resources, Y.-C.C.; data curation, Y.-C.C.; writing-original draft preparation, Y.-C.C. and H.-L.L.; writing-review and editing, H.-L.L.; visualization, H.-L.L.; supervision, H.-L.L.; project administration, H.-L.L.; funding acquisition, H.-L.L. All authors have read and agreed to the published version of the manuscript.

Funding: The authors would like to thank the Ministry of Education (MOE), Taiwan, for the support through the Higher Education Sprout Project.

Conflicts of Interest: The authors declare no conflict of interest.

\section{References}

1. United Nations. Transforming Our World: The 2030 Agenda for Sustainable Development. Resolution Adopted by the General Assembly on 25 September 2015. Available online: http://www.un.org/ga/search/ view_doc.asp?symbol=A/RES/70/1\&Lang=E (accessed on 26 March 2020).

2. Owens, T.L. Higher Education in the Sustainable Development Goals Framework. Eur. J. Educ. 2017, 52, 414-420. [CrossRef]

3. Boni, A.; Lopez-Fogues, A.; Walker, M. Higher Education and the Post-2015 Agenda: A Contribution from the Human Development Approach. J. Glob. Ethics 2016, 12, 17-28. [CrossRef]

4. Sonetti, G.; Brown, M.; Naboni, E. About the triggering of UN sustainable development goals and regenerative sustainability in higher education. Sustainability 2019, 11, 254. [CrossRef]

5. Crespo, B.; Míguez-Álvarez, C.; Arce, M.E.; Cuevas, M.; Míguez, J.L. The sustainable development goals: An experience on higher education. Sustainability 2017, 9, 1353. [CrossRef]

6. Leal Filho, W.; Vargas, V.R.; Salvia, A.L.; Brandli, L.L.; Pallant, E.; Klavins, M.; Ray, S.; Moggi, S.; Maruna, M.; Conticelli, E.; et al. The role of higher education institutions in sustainability initiatives at the local level. J. Clean. Prod. 2019, 233, 1004-1015. [CrossRef]

7. Zamora-Polo, F.; Sánchez-Martín, J. Teaching for a better world. Sustainability and sustainable development goals in the construction of a change-maker university. Sustainability 2019, 11, 4224. [CrossRef]

8. Presidents \& Vice Presidents Since 1947. Available online: https://english.president.gov.tw/Page/81 (accessed on 22 April 2020).

9. Ministry of Foreign Affairs, Republic of China (Taiwan). Available online: https://www.taiwan.gov.tw/ content_9.php (accessed on 22 April 2020).

10. Hölscher, K.; Wittmayer, J.M.; Loorbach, D. Transition versus Transformation: What's the Difference? Environ. Innov. Soc. Transit. 2018, 27, 1-3. [CrossRef]

11. Smith, A.; Voß, J.-P.; Grin, J. Innovation studies and sustainability transitions: The allure of the multi-level perspective and its challenges. Res. Policy 2010, 39, 435-448. [CrossRef]

12. Markard, J.; Raven, R.; Truffer, B. Sustainability transitions: An emerging field of research and its prospects. Res. Policy 2012, 41, 955-967. [CrossRef]

13. Leal Filho, W. Viewpoint: Accelerating the Implementation of the SDGs. Int. J. Sustain. High. Edu. 2020, 21, 507-511. [CrossRef]

14. Deleye, M.; Van Poeck, K.; Block, T. Lock-ins and opportunities for sustainability transition: A multi-level analysis of the flemish higher education system. Int. J. Sustain. High. Edu. 2019, 20, 1109-1124. [CrossRef]

15. Vladimirovaa, K.; Le Blanc, D. How Well are the Links Between Education and Other Sustainable Development Goals Covered in UN Flagship Reports? A Contribution to the Study of the Science-Policy Interface on Education in the UN System; DESA Working Paper; UN Secretariat: New York, NY, USA, 2015; p. 146.

16. Lozano, R.; Lukman, R.; Lozano, F.J.; Huisingh, D.; Lambrechts, W. Declarations for sustainability in higher education: Becoming better leaders through addressing the university system. J. Clean. Prod. 2013, 48, 10-19. [CrossRef]

17. Leal Filho, W.; Wu, Y.-C.J.; Brandli, L.L.; Avila, L.V.; Azeiteiro, U.M.; Caeiro, S.; Madruga, L.R.; da, R.G. Identifying and overcoming obstacles to the implementation of sustainable development at universities. J. Integr. Environ. Sci. 2017, 14, 93-108. [CrossRef] 
18. Lozano, R. Incorporation and institutionalization of SD into universities: Breaking through barriers to change. J. Clean. Prod. 2006, 14, 787-796. [CrossRef]

19. SDSN Australia/Pacific. Getting Started with the SDGs in Universities: A Guide for Universities, Higher Education Institutions, and the Academic Sector; Australia, New Zealand and Pacific Edition; Sustainable Development Solutions Network - Australia/Pacific: Melbourne, Australia, 2017.

20. Berghaeuser, H.; Hoelscher, M. Reinventing the third mission of higher education in Germany: Political frameworks and universities' reactions. Tert. Educ. Manag. 2019, 26, 1-20. [CrossRef]

21. Leal Filho, W.; Shiel, C.; Paço, A.; Mifsud, M.; Ávila, L.V.; Brandli, L.L.; Molthan-Hill, P.; Pace, P.; Azeiteiro, U.M.; Vargas, V.R.; et al. Sustainable development goals and sustainability teaching at universities: Falling behind or getting ahead of the pack? J. Clean. Prod. 2019, 232, 285-294. [CrossRef]

22. Dmochowski, J.E.; Garofalo, D.; Fisher, S.; Greene, A.; Gambogi, D. Integrating sustainability across the university curriculum. Int. J. Sustain. High. Educ. 2016, 17, 652-670. [CrossRef]

23. STARS (2019) STARS Technical Manual AC 01 Academic Courses v.2.2. AASHE, Philadephia, PA, USA. Available online: https://drive.google.com/file/d/1Q97iPiX1_tvq5cjgQ3qfCch99L-0-Gt1/view. (accessed on 22 April 2020).

24. Orlovic Lovren, V.; Maruna, M.; Stanarevic, S. Reflections on the Learning Objectives for Sustainable Development in the Higher Education Curricula-Three Cases from the University of Belgrade. Int. J. Sustain. High. Edu. 2020, 21, 15-335. [CrossRef]

25. Albareda-Tiana, S.; Vidal-Raméntol, S.; Fernández-Morilla, M. Implementing the sustainable development goals at university level. Int. J. Sustain. High. Educ. 2018, 19, 473-497. [CrossRef]

26. Brugmann, R.; Côté, N.; Postma, N.; Shaw, E.A.; Pal, D.; Robinson, J.B. Expanding student engagement in sustainability: Using SDG-and CEL-focused inventories to transform curriculum at the university of Toronto. Sustainability 2019, 11, 530. [CrossRef]

27. Gough, G.; Longhurst, J. Monitoring Progress towards implementing sustainability and representing the UN sustainable development goals (SDGs) in the curriculum at UWE Bristol. In Implementing Sustainability in the Curriculum of Universities; Springer: Cham, Switzerland, 2018; pp. 279-289.

28. Kosta, K. Sustainability curriculum in UK university sustainability reports. In Implementing Sustainability in the Curriculum of Universities; Springer: Cham, Switzerland, 2018; pp. 79-97.

29. The Online Syllabus System of NUK (Chinese Version). Available online: https://course.nuk.edu.tw/ QueryCourse/QueryCourse.asp (accessed on 22 April 2020).

30. Willats, J.; Erlandsson, L.; Molthan-Hill, P.; Dharmasasmita, A.; Simmons, E. A university wide approach to embedding the sustainable development goals in the curriculum-A case study from the nottingham trent university's green academy. In Implementing Sustainability in the Curriculum of Universities; World Sustainability Series; Springer: Cham, Switzerland, 2017; pp. 63-78.

31. Janoušková, S.; Hák, T.; Moldan, B. Global SDGs assessments: Helping or confusing indicators? Sustainability 2018, 10, 1540. [CrossRef]

32. NUK Sustainability Report (2019). Available online: http://sdg.nuk.edu.tw/defaultEn.aspx (accessed on 20 March 2020).

33. The SDG University of Taiwan: National University of Kaohsiung (NUK) Initiative for SDGs. Available online: http://sdg.nuk.edu.tw/defaultEn.aspx (accessed on 26 March 2020).

34. Taiwan Institute for Sustainable Energy (TAISE). The Alliance for Sustainable Development Goals Founding Ceremony Leading Taiwan to a New Sustainable Future. Available online: https://www.taiseen.org.tw/newsview.php?ID=72 (accessed on 22 April 2020).

35. Universities for SDG Forum at NUK. Available online: http://nukforum2019.mystrikingly.com/ (accessed on 22 April 2020).

36. Times Higher Education (THE) Impact Rankings. Available online: https://www.timeshighereducation.com/ rankings/impact/2020/overall\#!/page/0/length/25/sort_by/rank/sort_order/asc/cols/undefined (accessed on 22 April 2020).

37. Osman, A.; Ladhani, S.; Findlater, E.; McKay, V. Curriculum Framework for the Sustainable Development Goals; The Commonwealth Secretariat: London, UK, 2017.

38. White, G.B.; Koester, R.J. STARS and GRI: Tools for campus greening strategies and prioritizations. Sustain. J. Rec. 2012, 5, 100-106. [CrossRef] 
39. Klein, J.T. Sustainability and collaboration: Crossdisciplinary and cross-sector horizons. Sustainability 2020, 12, 1515. [CrossRef]

40. Ely, A.; Marin, A.; Charli-Joseph, L.; Abrol, D.; Apgar, M.; Atela, J.; Ayre, B.; Byrne, R.; Choudhary, B.K.; Chengo, V.; et al. Structured collaboration across a transformative knowledge network-Learning across disciplines, cultures and contexts? Sustainability 2020, 12, 2499. [CrossRef]

41. Annan-Diab, F.; Molinari, C. Interdisciplinarity: Practical approach to advancing education for sustainability and for the Sustainable Development Goals. Int. J. Manag. Educ. 2017, 15, 73-83. [CrossRef]

42. Leal Filho, W.; Raath, S.; Lazzarini, B.; Vargas, V.R.; de Souza, L.; Anholon, R.; Quelhas, O.L.G.; Haddad, R.; Klavins, M.; Orlovic, V.L. The role of transformation in learning and education for sustainability. J. Clean. Prod. 2018, 199, 286-295. [CrossRef]

43. Zamora-Polo, F.; Sánchez-Martín, J.; Corrales Serrano, M.; Espejo-Antúnez, L. What do university students know about sustainable development goals? A realistic approach to the reception of this UN program amongst the youth population. Sustainability 2019, 11, 3533. [CrossRef]

(C) 2020 by the authors. Licensee MDPI, Basel, Switzerland. This article is an open access article distributed under the terms and conditions of the Creative Commons Attribution (CC BY) license (http://creativecommons.org/licenses/by/4.0/). 